\title{
Evaluation of eight protocols for genomic DNA extraction of Hypostomus commersoni Valenciennes, 1836 (Loricariidae: Siluriformes)
}

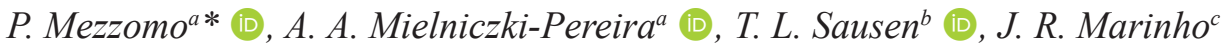 \\ and R. L. Cansian ${ }^{a}$
}

\begin{abstract}
${ }^{a}$ Universidade Regional Integrada - URI, Programa de Pós-graduação em Ecologia - PPGECOL, Departamento de Ciências Biológicas, Laboratório de Bioquímica e Biologia Molecular, Erechim, RS, Brasil

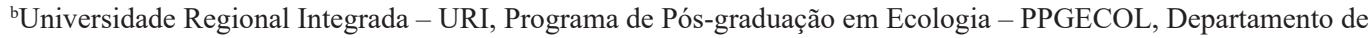
Ciências Biológicas, Laboratório de Ecofisiologia Vegetal, Erechim, RS, Brasil

${ }^{c}$ Universidade Regional Integrada - URI, Programa de Pós-graduação em Ecologia - PPGECOL, Departamento de Ciências Biológicas, Laboratório de Ecologia de Fauna - ECOFAUNA, Erechim, RS, Brasil

*e-mail: priscilamez@gmail.com
\end{abstract}

Received: September 26, 2019 - Accepted: March 28, 2020 - Distributed: August 31, 2021

(With 1 figure)

\begin{abstract}
The principle and the techniques applied in DNA extraction play a pivotal role in the obtention of a purified genetic material. The present study investigates the efficiency of eight protocols in the DNA extraction of Hypostomus commersoni, an essential component of South American freshwater ichthyofauna. The quality of samples was assessed through spectrophotometry, gel electrophoresis, and PCR-RAPD markers amplification. The efficiency of DNA extraction was influenced both by the method applied and the target-tissue of choice. Higher concentrations and yield of DNA were obtained from ocular tissue, with a positive spectrum of incubation in lysis buffer for up to 36 hours after sample collection, using fresh tissues and in the presence of a high concentration of Proteinase K $\left(20 \mathrm{mg}^{-\mathrm{ml}^{-1}}\right)$. In these conditions, samples were successfully amplified. To date, there is no record of description for the parameters analyzed in this work, neither the description of RAPD markers for the species $H$. commersoni.
\end{abstract}

Keywords: DNA extraction, PCR-RAPD, eye tissue, Proteinase K, suckermouth catfish.

\section{Avaliação de oito protocolos na extração de DNA genômico de Hypostomus commersoni Valenciennes, 1836 (Loricariidae: Siluriformes)}

\section{Resumo}

Os princípios e as técnicas aplicadas na extração de DNA desempenham um papel crucial na obtenção de material genético purificado. O presente estudo investiga a eficiência de oito protocolos na extração de DNA de Hypostomus commersoni, um importante componente ictiofaunístico de riachos da América do Sul. A qualidade das amostras foi avaliada por espectrofotometria, eletroforese em gel e amplificação por marcadores de PCR-RAPD. A eficiência da extração de DNA foi influenciada tanto pelo método aplicado quanto pelo tecido-alvo de escolha. Maiores concentrações e rendimento de DNA foram obtidos a partir do tecido ocular, com um espectro positivo de incubação em tampão de lise por até 36 horas após a coleta da amostra, utilizando tecidos frescos e na presença de alta concentração de proteinase $\mathrm{K}\left(20 \mathrm{mg} \cdot \mathrm{ml}^{-1}\right)$. Nestas condições, as amostras foram amplificadas com sucesso. Até o momento, não há registro de descrição para os parâmetros analisados neste trabalho, nem a descrição de marcadores RAPD para a espécie H. commersoni.

Palavras-chave: extração de DNA, PCR-RAPD, tecido ocular, Proteinase K, cascudo.

\section{Introduction}

A crucial step for high-quality genetic analysis is considered to be a satisfactory DNA extraction. Nevertheless, this purpose is not always easy to achieve, since different biological compounds, such as lipids and proteins, can act as contaminants and interfere in the final quality of the product (Bauer and Patzelt, 2003). The principles and techniques applied in DNA extraction play a pivotal role in obtaining a considerable and purified yield of this molecule (Muhammad et al., 2016). 
A variety of methods has been established to isolate DNA from biological materials (Milligan, 1998; Reischl et al., 2000; Rantakokko-Jalava and Jalava, 2002; van Tongeren et al., 2011). Regardless of the method of choice, the procedure usually consists of three steps: lysis, purification, and DNA recovery; being the first stage the most critical one since it is at this point that the chances of causing DNA damages are higher (Barbosa et al., 2015).

The quality and amount of available DNA strand template have a significant influence on genetic analyzes based on PCR (Polymerase Chain Reaction), for example (Ward et al., 2009; Wang et al., 2011). Therefore, an ideal extraction technique should optimize DNA yield, minimize DNA degradation, and be efficient in terms of cost, time, labor, and supplies required (Chen et al., 2010).

With the availability of a plethora of molecular analysis machinery, there is an exponential demand for high-quality samples, capable of generating great results with a minimum of errors. To accomplish this, commercial kits were developed, aiming for DNA extractions of excellence (Coombs et al., 1999; Barea et al., 2004; Bueno, 2004).

However, the market price of these products is not always easily affordable (Chen et al., 2010; Mega and Revers, 2011). On the other hand, the extraction of genetic material using reagents of homemade preparation can be less costly, and, therefore, such methodologies can be replicated in laboratories with a limited budget.

Establish a well-succeed protocol for DNA extraction is a crucial step in genetic analysis, considering that the same methodology may present variations between different organisms (Lucentini et al., 2006). Furthermore, the quality of isolated DNA through methods described for other taxa generally presents unsatisfactory results when applied to fish species (Muhammad et al., 2016).

Hypostomus commersoni (Valenciennes, 1836), commonly known as suckermouth catfish, is an essential component of freshwater ichthyofauna, inhabiting the Paraná and Uruguay basins, in South America (Burgess, 1989; Reis et al., 2003). This taxon is marked by its ecological and commercial relevance (Buck and Sazima, 1995; Garavello and Garavello, 2004; Baldisserotto, 2009; Gonçalves, 2011; Lujan et al., 2012), and, despite that, there is no record of description of well-succeed DNA extraction protocol nor the description of PCR-RAPD markers for this organism to date. In this work, we evaluated eight protocols in the extraction of the genomic DNA of $H$. commersoni, aiming to obtain high-quality DNA samples of this specie.

\section{Material and Methods}

\subsection{Ethics Statement}

This study was approved by the CEUA(Ethics Committee for Animal Use, Protocol $n^{\circ}$ 79) of URI (Universidade Regional Integrada). Written informed consent was obtained from the regulatory organ.

\subsection{Sample collection}

Forty specimens of Hypostomus commersoni $(24 \mathrm{~cm} \pm 114 \mathrm{~g})$ were collected in a small tributary from the Upper Rio Uruguay basin in the municipality of Erechim, South Brazil. The fishes were subjected to euthanasia, using clove oil at a concentration of $0.1 \%$. Specimens were allocated in a recipient containing river water from the collection site, in which the clove oil was applied. The tissues previously selected for DNA extraction were removed and placed in a sterile $2 \mathrm{~mL}$ Eppendorf tube for subsequent analysis. Vouchers specimens were deposited in the ichthyological collection of the Museu Regional do Alto Uruguai (MuRAU) of URI-Erechim, Brazil (MuRAU - PEIXES 715-716).

\subsection{DNA extraction}

All DNA was extracted and quantified at the biochemistry and molecular biology laboratory of URI. Seven protocols for DNA extraction were selected from the literature, whose methodologies had previously been described for fish species or whose parameters were similar to those intended to be analyzed in this work, such as the same extraction conditions or target-tissues (Doyle and Doyle, 1987; Medrano et al., 1990; Whitmore et al., 1992; Aljanabi and Martinez, 1997; Faleiro et al., 2003; Barrero et al., 2008; Mossi et al., 2014). An eighth protocol was proposed and evaluated, combining the variables that presented better results in the extraction of $H$. commersoni DNA in each of the seven tested protocols. The full description of the protocols one to seven is available as Supplementary Material (S1). The eighth protocol is described in full in the results section.

In combination with the protocols, we also evaluate eight different variables that, based on literature findings and our previous analysis, were thought to influence the purity and amount of the obtained DNA, as follows:

a. Forms of sample preservation:

1. Fresh tissues: When the specimen is collected, immediately submitted to euthanasia, and right after the tissue is removed and submitted to DNA extraction.

2. Tissues stored in $70 \%$ and $95 \%$ ethanol: When the specimen is collected, immediately submitted to euthanasia, and right after the tissue is removed, and stored in tubes containing ethanol at room temperature (approximately $27^{\circ} \mathrm{C}$ ), until its use.

3. Tissues stored at $-10{ }^{\circ} \mathrm{C}$ or $-20^{\circ} \mathrm{C}$ : When the specimen is collected, immediately submitted to euthanasia, and tissues are removed and directly frozen until its use.

b. Forms of sample maceration: 
1. Chemical lysis: Samples submerse in lysis buffer, tubes placed on a water bath at $27^{\circ} \mathrm{C}$, without mixing.

2. Mechanical lysis: Samples submersed in lysis buffer and mixed using the vortex.

3. Lysis with liquid nitrogen $\left(L N_{2}\right)$ : Samples triturated; fragments placed in tubes with lysis buffer on a water bath at $27^{\circ} \mathrm{C}$.

4. Manual lysis: Samples smashed using a sterile glass stick, and then placed in tubes with lysis buffer on a water bath at $27^{\circ} \mathrm{C}$.

c. Different target-tissues: dorsal fin, caudal fin, muscle, gills, blood, and ocular tissue.

d. Times of incubation in extraction buffer: one hour $\left(55^{\circ} \mathrm{C}\right), 12$ hours $\left(27^{\circ} \mathrm{C}\right), 24$ hours $\left(27^{\circ} \mathrm{C}\right)$, and 36 hours $\left(27^{\circ} \mathrm{C}\right)$, for all the conditions mentioned in items $a$ and $b$.

e. RNAse: presence or absence.

f. Proteinase K: presence or absence, with different gradients of concentration ( $05 \mathrm{mg} \cdot \mathrm{ml}^{-1}, 1 \mathrm{mg} \cdot \mathrm{ml}^{-1}, 20$ $\mathrm{mg} \cdot \mathrm{ml}^{-1}$ and $\left.200 \mathrm{mg} \cdot \mathrm{ml}^{-1}\right)$.

g. Storage after extraction: at $4{ }^{\circ} \mathrm{C},-10{ }^{\circ} \mathrm{C}$ or $-20^{\circ} \mathrm{C}$.

h. Integrity and quantification: on the day of extraction, after 10,20, and 30 days of storage.

Several tests aiming for experimental optimization were performed, and for each variable, the factors that implicated in better concentration and purity of DNA were selected. The results were categorized into a qualitative matrix, according to the effect on the final extracted product: a. Efficient: satisfactory concentration and purity; b. Indifferent: did not influence the parameters evaluated; c. Inefficient: low concentration of genetic material, low purity, or degradation of samples.

\subsection{Analysis of DNA integrity}

The integrity of the samples was verified through agarose gel $(0,8 \%)$ electrophoresis, stained with ethidium bromide $(1 \mathrm{mg} / \mathrm{ml})$. The reaction runs for 150 minutes at 90 volts, and the visualization and image caption of the gel was obtained under ultraviolet (UV) light.

\subsection{Evaluation of concentration and purity of DNA}

The samples whose extraction was successful according to the electrophoresis verification were then submitted to spectrophotometry and analyzed for protein contamination (purity). Samples were quantified in a spectrophotometer (model NI 1600UV - Nova Instruments) at the wavelengths of $A_{260}$ and $A_{280}$ nanometers (nm). The purity of the DNA was confirmed by the ratio of absorbance values at the two wavelengths measured (Barbosa, 1998). The DNA concentration of each sample was determined by the equation: $[\mathrm{DNA}]=50 \mu \mathrm{g} / \mathrm{ml} \times \mathrm{D}$ (dilution factor) $\mathrm{A} \mathrm{A}_{260}$ (read value obtained in the wavelength of $260 \mathrm{~nm}$ ). Satisfactory purity values were considered to be ranging between 1.7-2.0.

\subsection{DNA amplification with PCR-RAPD markers}

The final quality assessment of the samples was verified through their amplification with RAPD markers. Samples that reached the above parameters of DNA concentration and yield were submitted to amplification with different primers of PCR-RAPD. In total, 32 primers from Operon Technologies sets OPA $(01,02,03,04,05,06,07,08,09)$, OPB $(03,05,07,10,11,15)$, OPF $(10,11,12$ e 13), OPW $(01,02,03,04,05,06,07,08,09,10)$ and OPY $(01,02,03)$ were tested. Since the RAPD technique is sensitive to changes in reaction parameters (e.g., primer, $\mathrm{MgCl} 2$, dNTP concentrations) (Chiappero and Gardenal, 2001), the same reaction conditions were used for all samples. Ten nanograms of genomic DNA was amplified in PCR buffer (20 mM Tris- $\mathrm{HCl} \mathrm{pH} \mathrm{8.4,50} \mathrm{mM} \mathrm{KCl),}$ $4 \mathrm{mM} \mathrm{MgCl}, 0.7 \mathrm{mM}$ dNTPs, $0.3 \mu \mathrm{M}$ primers e one unity of Taq DNA polymerase enzyme (Invitrogen). The reaction was conducted in a final volume of $25 \mu \mathrm{L}$, in the following conditions: denaturation at $95{ }^{\circ} \mathrm{C}$ for 30 seconds, annealing at $50{ }^{\circ} \mathrm{C}$ for $1 \mathrm{~min}$, and extension at $72{ }^{\circ} \mathrm{C}$ for $5 \mathrm{~min}$ totaling 40 cycles. The amplification products were applied in agarose gel (1.5\%), stained with ethidium bromide $(1 \mathrm{mg} / \mathrm{ml})$. The reaction runs for 150 minutes at $150 \mathrm{~V}$. Visualization and image caption of band patterns was obtained under ultraviolet (UV) light.

\subsection{Data analysis}

Statistical analysis was performed using the Software Python (version 3.6.0). Differences between DNA extraction methods in total DNA concentration were determined by ANOVA using Tukey HSD as a post-hoc test.

\section{Results}

\subsection{DNA extraction method impacts DNA yield}

Our study has shown that a method that uses in-house produced reagents instead of commercial kits for DNA extraction can generate samples with sufficient quality to be used in molecular analysis, as PCR-RAPD amplifications. The amount of DNA extracted was dependent on the technique and the target-tissue of choice. For all variables examined, the improved extraction method developed and proposed at this work, produced the highest total DNA mean yields, for all tissues, resulting in significantly higher absorbance ratios when compared to the other extraction methods evaluated. The influence of each variable evaluated on the final DNA extraction is available in Table 1.

\subsection{An improved protocol for DNA extraction of Hypostomus commersoni}

The protocol proposed in this work presented, in general, the highest efficiency in the extraction of $H$. commersoni DNA. The samples submitted to extraction through this protocol were the only ones that amplified with PCR-RAPD primers. The complete methodology of this protocol is described in Table 2. 


\subsection{Analysis of DNA integrity in an electrophoresis gel}

All samples obtained from the six tissues and tested under the different conditions were submitted to gel electrophoresis in triplicate, resulting in a total count of 144 samples. The samples obtained from ocular tissue presented the highest integrity of extracted DNA, in all combinations of variables and protocols. For all tissues, the leading bands of DNA were around $46-48 \mathrm{~kb}$ in size. When comparing protocols, the EDTA methods (protocols two, seven, and eight) showed relatively lighter smear tails, indicating less DNA degradation.

Table 1. Effect of different variables in the total yield of extracted DNA from H. commersoni.

\begin{tabular}{|c|c|c|c|}
\hline Variables & Efficient & Indifferent & Inefficient \\
\hline \multirow[t]{2}{*}{ Specimens conservation } & Fresh tissues (approx. $27^{\circ} \mathrm{C}$ ) & - & $\begin{array}{c}\text { Tissues in } 70 \% \text { and } 95 \% \\
\text { ethanol at } 27^{\circ} \mathrm{C}\end{array}$ \\
\hline & & & Tissues at $-10^{\circ} \mathrm{C}$ and $-20^{\circ} \mathrm{C}$ \\
\hline \multirow[t]{2}{*}{ Maceration } & Chemical lysis & Lysis with $\mathrm{LN}_{2}$ & Mechanical lysis \\
\hline & & & Manual lysis \\
\hline \multirow[t]{5}{*}{ Target-Tissue } & Ocular tissue & - & Caudal fin \\
\hline & & & Dorsal fin \\
\hline & & & Muscle \\
\hline & & & Gills \\
\hline & & & Blood \\
\hline \multirow[t]{2}{*}{ Time of incubation } & $1 \mathrm{~h}\left(55^{\circ} \mathrm{C}\right)$ & - & - \\
\hline & $12 \mathrm{~h}, 24 \mathrm{~h}, 36 \mathrm{~h}\left(27^{\circ} \mathrm{C}\right)$ & & \\
\hline RNAse & Absence & Presence & - \\
\hline Proteinase K & $\begin{array}{l}\text { Presence in high concentration } \\
\qquad\left(20 \mathrm{mg} \cdot \mathrm{ml}^{-1}\right)\end{array}$ & - & - \\
\hline Storage after extraction & $-10^{\circ} \mathrm{C}$ & - & $4^{\circ} \mathrm{C}$ \\
\hline & $-20^{\circ} \mathrm{C}$ & & \\
\hline \multirow[t]{2}{*}{ Quantification } & In the day of the extraction & - & - \\
\hline & After 10,20 and 30 days of storage & & \\
\hline
\end{tabular}

Table 2. Description of reagents and steps for DNA extraction of H. commersoni through the method proposed in this work.

\begin{tabular}{ll}
\hline & \multicolumn{1}{c}{ Reagents } \\
\hline STE Buffer & $0.1 \mathrm{M} \mathrm{NaCl}+10 \mathrm{mM}$ Tris $+1 \mathrm{mM}$ EDTA $(\mathrm{pH} 8.0)$ \\
Lysis Buffer & $2.5 \mathrm{mM}$ Tris- $\mathrm{HCl} \mathrm{pH} 8.0+0.1 \mathrm{mM}$ EDTA $\mathrm{pH} 8.0+0.1 \% \mathrm{SDS}+8.0 \mathrm{mM} \mathrm{NaCl}$ \\
Proteinase K & $20 \mathrm{mg} \cdot \mathrm{mL}^{-1}$ \\
CIA & Chloroform + isoamylic alcohol $(1: 24 \mathrm{v} / \mathrm{v})$ \\
TE Buffer & $10 \mathrm{mM}$ Tris $\mathrm{pH} 8.0+1 \mathrm{mM} \mathrm{EDTA} \mathrm{pH} 8.0$ \\
TBE Buffer & $500 \mathrm{mM}$ Tris- $\mathrm{HCl}+60 \mathrm{mM}$ boric acid $+83 \mathrm{mM}$ EDTA \\
\hline
\end{tabular}

1. Collect $20 \mathrm{mg}$ of fresh tissue.

2. Wash in $500 \mu$ of STE (cold) and discard.

3. Add $500 \mu \mathrm{l}$ of lysis buffer, $2 \mu \mathrm{L}$ of $\beta$-Mercaptoetanol and $13 \mu \mathrm{l}$ of proteinase $\mathrm{K}$, in this order, and incubate at $55^{\circ} \mathrm{C}$ for 1 hour (alternatives include the incubation for 12,24 or 36 hours at $27^{\circ} \mathrm{C}$ ).

4. Add $700 \mu \mathrm{l}$ of CIA and homogenize by inversion.

5. Centrifuge for 10 minutes at $9,000 \mathrm{rpm}$ and transfer the supernatant to a new tube.

6. Repeat steps 4 and $5(3 x)$.

7. Transfer the aqueous phase to a new tube containing $900 \mu 1$ of absolute isopropanol (cold), homogenize by inversion.

8. Incubate for 2 hours at $-20^{\circ} \mathrm{C}$.

9. Centrifuge for 15 minutes at 9,000 rpm and discard the supernatant.

10. Wash the resulting pellet with ethanol analytical grade (cold).

11. Discard all the volume and incubate at $37^{\circ} \mathrm{C}$ for 15 minutes.

12. Add $100 \mu \mathrm{L}$ of TE buffer and incubate for 1 hour at approximately $27^{\circ} \mathrm{C}$.

13. Storage at $-10{ }^{\circ} \mathrm{C}$ until use. 


\subsection{Quantification and assessment of purity}

The resulting values of quantification for each DNA sample extracted under the different conditions and through the different protocols are presented in Tables 3 and 4, as well as in Figures 1a-f. The amount of DNA obtained, and final yield mean values varied between samples from different tissues, as well as between samples of the same tissue but extracted using different protocols.

When comparing samples, the ocular tissue had the highest mean yield of extracted DNA $(516 \mathrm{ng} / \mu \mathrm{l})$, while the lowest concentration was for the dorsal fin $(131 \mathrm{ng} / \mu \mathrm{l})$. Concerning the protocols, means between different tissues indicated that the lowest value was for extractions performed using protocol three $(216 \mathrm{ng} / \mu \mathrm{l})$. In comparison, the highest mean concentration of DNA was obtained with protocol eight $(438 \mathrm{ng} / \mu \mathrm{l})$. Statistically, there is no significant difference between most of the samples whose DNA was extracted from the tissue's dorsal fin, caudal fin, gills, and muscle. The major exceptions were blood and ocular tissue, which had similar p-values for most of the evaluated protocols.

Although the results were statistically similar when concerning the total amount of DNA obtained per sample, the mean values of the absorbance ratio presented marked variance. The values for the absorbance ratio were 1.2 (protocol four), 1.3 (protocols two, three, six and seven), 1.4 (protocols one and five), and 1.8 (protocol eight), indicating its higher efficiency over the other seven protocols.

\subsection{DNA extraction method influences PCR-RAPD amplification}

RAPD markers have been used to evaluate the genetic diversity in numerous organisms (Cooper, 2000; Ali et al., 2004; Torezan et al., 2005; Bickel et al., 2006). Studies on genetic conservation of fish populations from South American rivers have successfully applied such markers to access the genetic diversity of different fish species (Almeida et al., 2001; Dergam et al., 2002; Wasko and Galetti Junior, 2002; Leuzzi et al., 2004; Matoso et al., 2004; Wasko et al., 2004). Of the thirty-four primers tested, nine amplified the DNA of the evaluated specie in the concentrations of 40 and $20 \mathrm{ng} / \mu \mathrm{l}$. These can be applied in studies evaluating the genetic structure of $H$. commersoni. The score of bands varied between the amplification using different concentrations of DNA (Table 5).

Table 3. Mean of total DNA amount (ng/ $\mu \mathrm{l})$ extracted using eight different methods for six different tissues.

\begin{tabular}{|c|c|c|c|c|c|c|c|}
\hline \multirow{3}{*}{ Method (Protocol) } & $\mathbf{C F}$ & DF & MC & GL & BD & OT & \multirow{3}{*}{$\begin{array}{c}\text { Methods } \\
\text { mean } \\
(\mathrm{ng} / \mu \mathrm{l})\end{array}$} \\
\hline & \multicolumn{6}{|c|}{ Total DNA amount $(\mathrm{ng} / \mu \mathrm{l})$} & \\
\hline & \multicolumn{6}{|c|}{ Mean \pm SD } & \\
\hline 1. Doyle and Doyle (1987) & $120 \pm 21.2$ & $139 \pm 26.9$ & $198 \pm 10.6$ & $110 \pm 22$ & $365 \pm 60.4$ & $400 \pm 26.8$ & 222 \\
\hline 2. Medrano et al. (1990) & $175 \pm 8.6$ & $114 \pm 23.7$ & $155 \pm 32.8$ & $137 \pm 27.8$ & $375 \pm 115.2$ & $520 \pm 62.8$ & 246 \\
\hline 3. Whitmore et al. (1992) & $116 \pm 18.0$ & $74 \pm 19$ & $173 \pm 35.3$ & $125 \pm 6.5$ & $335 \pm 70.3$ & $455 \pm 48.8$ & 216 \\
\hline 4. Aljanabi and Martinez (1997) & $181 \pm 17.3$ & $90 \pm 12.3$ & $120 \pm 33.2$ & $110 \pm 12.6$ & $455 \pm 60.1$ & $465 \pm 50.9$ & 237 \\
\hline 5. Faleiro et al. (2003) & $168 \pm 39.9$ & $150 \pm 24.5$ & $205 \pm 28.1$ & $155 \pm 10.6$ & $425 \pm 20.4$ & $505 \pm 63.9$ & 268 \\
\hline 6. Barrero et al. (2008) & $157 \pm 29.0$ & $97 \pm 9.6$ & $207 \pm 32.6$ & $175 \pm 18.7$ & $460 \pm 51.9$ & $555 \pm 47.3$ & 275 \\
\hline 7. Coppini (2009) & $186 \pm 6.6$ & $160 \pm 44.4$ & $170 \pm 19.1$ & $135 \pm 1.6$ & $330 \pm 17.1$ & $516 \pm 22.2$ & 250 \\
\hline 8. Improved protocol (2020) & $209 \pm 15.7$ & $220 \pm 33.5$ & $216 \pm 0.8$ & $210 \pm 4.1$ & $463 \pm 9.7$ & $712 \pm 18.8$ & 438 \\
\hline Tissues Mean & 164 & 131 & 180 & 145 & 404 & 516 & - \\
\hline
\end{tabular}

$\mathrm{CF}=$ caudal fin, $\mathrm{DF}=$ dorsal fin, $\mathrm{MC}=$ muscle, $\mathrm{GL}=$ gills, $\mathrm{BD}=$ blood, $\mathrm{OT}=$ ocular tissue. Sample values are from reading in the wavelength of $260 \mathrm{~nm}$ applied to the equation [DNA] $=50 \mu \mathrm{g} / \mathrm{mL} \times \mathrm{D}$ (dilution factor) $\mathrm{x}$ A260 to obtain its concentration in ng per $\mu 1$.

Table 4. The mean of DNA amount from ratio $260 / 280 \mathrm{~nm}$, extracted using eight different methods for six different tissues.

\begin{tabular}{|c|c|c|c|c|c|c|c|}
\hline \multirow{3}{*}{ Method (Protocol) } & $\mathbf{C F}$ & DF & MC & GL & BD & OT & \multirow{3}{*}{$\begin{array}{c}\text { Methods } \\
\text { Mean }\end{array}$} \\
\hline & \multicolumn{6}{|c|}{ Absorbance ratio (OD 280/260 nm) } & \\
\hline & \multicolumn{6}{|c|}{ Mean \pm SD } & \\
\hline 1, Doyle and Doyle (1987) & $1.5 \pm 0.016$ & $0.8 \pm 0.08$ & $1.4 \pm 0.08$ & $1 \pm 0$ & $1.9 \pm 0.08$ & $1.8 \pm 0.12$ & 1.4 \\
\hline 2, Medrano et al. (1990) & $1.8 \pm 0.08$ & $0.6 \pm 0.08$ & $1.6 \pm 0.08$ & $1 \pm 0.08$ & $1.4 \pm 0.08$ & $1.6 \pm 0.08$ & 1.3 \\
\hline 3, Whitmore et al. (1992) & $1 \pm 0.14$ & $0.7 \pm 0.08$ & $1.6 \pm 0.08$ & $1.2 \pm 0$ & $1.6 \pm 0.08$ & $1.8 \pm 0.08$ & 1.3 \\
\hline 4, Aljanabi and Martinez (1997) & $1.1 \pm 0.16$ & $0.8 \pm 0.08$ & $1 \pm 0.08$ & $1 \pm 0$ & $1.7 \pm 0.08$ & $1.6 \pm 0.08$ & 1.2 \\
\hline 5, Faleiro et al. (2003) & $1.1 \pm 0.08$ & $0.9 \pm 0.08$ & $1.6 \pm 0.08$ & $1.1 \pm 0.14$ & $1.6 \pm 0$ & $1.9 \pm 0.08$ & 1.4 \\
\hline 6, Barrero et al. (2008) & $1.1 \pm 0.08$ & $0.9 \pm 0.08$ & $1.3 \pm 0.08$ & $1.2 \pm 0$ & $1.8 \pm 0.08$ & $1.7 \pm 0.08$ & 1.3 \\
\hline 7, Coppini (2009) & $1.5 \pm 0.08$ & $1.1 \pm 0.12$ & $0.8 \pm 0.08$ & $1.1 \pm 0.08$ & $1.6 \pm 0$ & $1.8 \pm 0.08$ & 1.3 \\
\hline 8, Improved protocol (2019) & $2 \pm 0$ & $1.5 \pm 0.08$ & $1.7 \pm 0.08$ & $1.5 \pm 0.08$ & $1.9 \pm 0.08$ & $2 \pm 0.08$ & 1.8 \\
\hline Tissues Mean & 1.4 & 0.9 & 1.3 & 1.1 & 1.7 & 1.8 & - \\
\hline
\end{tabular}

$\mathrm{CF}=$ caudal fin, $\mathrm{DF}=$ dorsal fin, $\mathrm{MC}=$ muscle, $\mathrm{GL}=$ gills, $\mathrm{BD}=$ blood, $\mathrm{OT}=$ ocular tissue, Sample values are from the ratio of the reads in the wavelength of 260 and 280 nanometers, that quantifies the purity of DNA in the samples. 

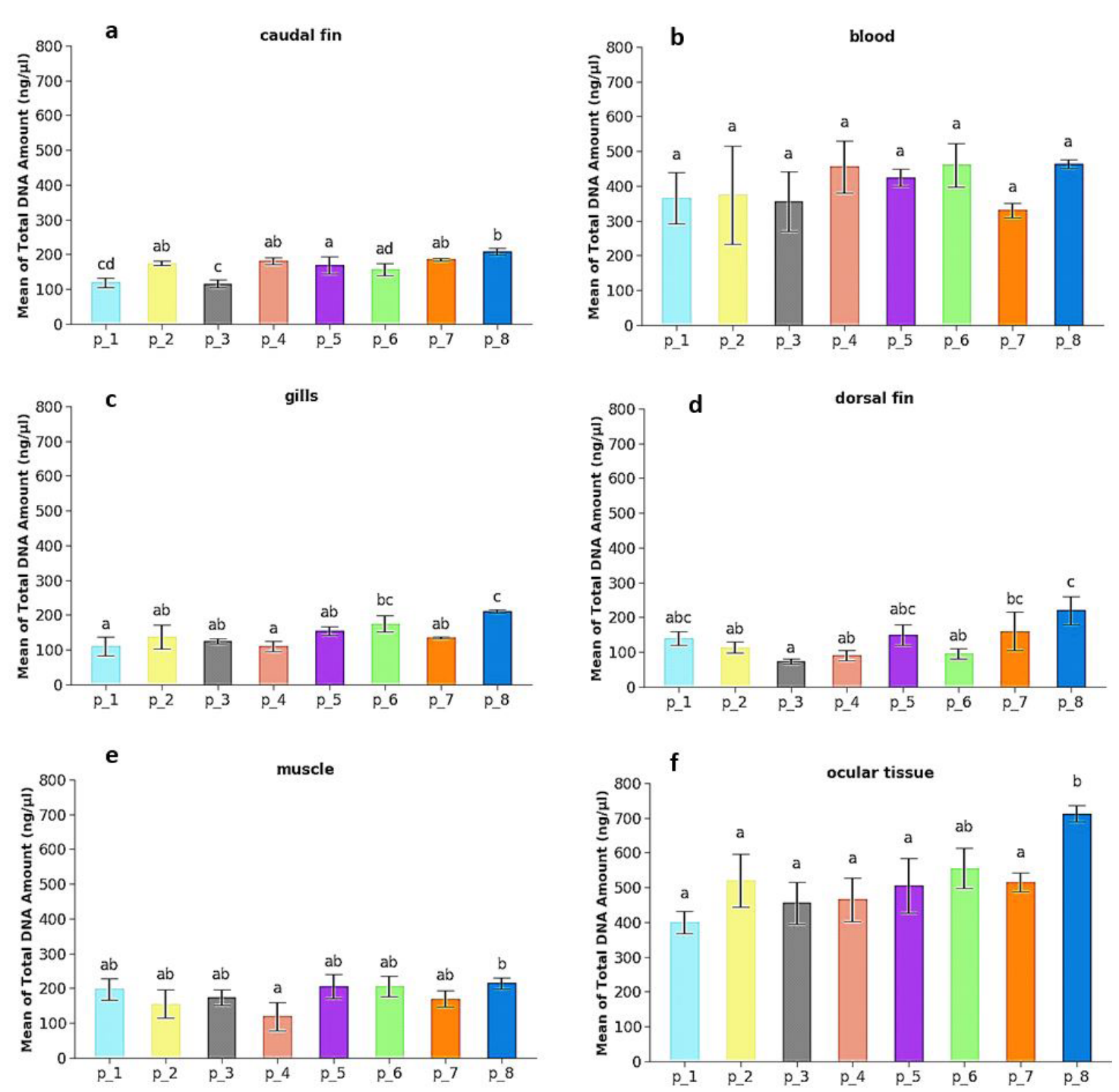

Figure 1. Genomic DNA extraction efficiency of Hypostomus commersoni varies dependent on the extraction method and target tissue. Mean total amount ( \pm standard deviation) of DNA extracted from caudal fin (a), blood (b), gills (c), dorsal fin (d), muscle (e), and ocular tissue (f), using eight DNA extraction protocols. Samples were extracted, and DNA was quantified by spectrometry. Statistical significance was determined using one way ANOVA with Tukey HSD post hoc test. Significance defined by $\mathrm{p} \leq 0.05$ and denoted by lower case letters. Whiskers indicating lower standard deviation are cropped at zero.

Table 5. Score of DNA bands amplified for each primer.

\begin{tabular}{ccccc}
\hline \multirow{2}{*}{ Primer } & Sequence 5' $\mathbf{- 3}$, & \multicolumn{3}{c}{ Score of Amplified DNA bands } \\
\cline { 3 - 5 } & CTCAGTGTCC & $\mathbf{4 0} \mathbf{~ n g / \mu l}$ & $\mathbf{2 0} \mathbf{~ n g} / \boldsymbol{\mu l}$ & $\mathbf{1 0} \mathbf{~ n g} / \boldsymbol{\mu l}$ \\
\hline OPW-01 & 6 & 6 & 6 \\
OPW-02 & ACCCCGCCAA & 6 & 8 & 8 \\
OPW-03 & GTCCGGAGTG & 4 & 8 & 7 \\
OPW-05 & CAGAAGCGGA & 7 & 9 & 7 \\
OPW-06 & GGCGGATAAG & 4 & 4 & - \\
OPW-07 & AGGCCCGATG & 7 & 8 & - \\
OPW-08 & CTGGACGTCA & 7 & 8 & - \\
OPW-09 & GACTGCCTCT & 5 & 5 & - \\
\hline
\end{tabular}


The concentration of $20 \mathrm{ng} / \mu$ l generated the major count of fragments, followed by a concentration of $40 \mathrm{ng} / \mu \mathrm{l}$. At the concentration of $10 \mathrm{ng} / \mu \mathrm{l}$, the DNA samples did not amplify with the primers OPW05, OPW06, OPW07, OPW08, and OPW09. Therefore, this is the less indicated of the tested concentrations to be used in the PCR-RAPD reaction with this set of primers and specie, according to our findings.

\section{Discussion}

The relevance to describe an efficient method for DNA extraction for the species $H$. commersoni is justified by the fact that obtaining high-quality samples is crucial for studying organisms at the genetic level. Specifically, in the case of $H$. commersoni, there are few molecular data available in the literature. The information compilated at this work may allow future analyzes and the genetic characterization of the group and, nevertheless, the techniques described here may as well be used to study other fish species.

In this study, we proposed a methodology based on the DNA extraction obtained from ocular tissue, and, to our knowledge, there is no record of this parameter for any fish species to date. The use of this tissue may present some limitations, such as its availability in number and size in organisms. Still, our results indicate that this organ has excellent potential as a source for extract high-quality genomic DNA of $H$. commersoni and possibly for other species.

This technique can be useful in cases where DNA extraction is performed using samples belonging to scientific collections, where the specimens have already been euthanized and are stored for long periods. Potentially, it can also be applied when an alternative model of extraction source is required, once the classical ones (generally from gills, fins, and muscle) have been exhausted without having presented a positive result.

During the test period, all the steps that were shown to be promising regarding the primary objective of our study were selected, aiming to group them into a single protocol, considered the "ideal" one for the $H$. commersoni. In this sense, it is possible to discuss some of the characteristics that presented better efficiency in terms of isolated DNA.

The use of liquid nitrogen for tissue maceration in DNA extractions, especially in solid tissues, is a method commonly described as efficient (Chen and Leibenguth, 1995). However, in this work, it was not a factor of influence both on the quality or quantity of product obtained. The non-use of such reagent implies a protocol of lower cost and greater ease of execution, facilitating the application of this methodology within a large number of laboratories and research groups.

The addition of RNAse is suggested as necessary in protocols for extracting fish DNA, being used to eliminate the contamination of the samples by RNA, consequently increasing DNA purity (Wasko et al., 2003). However, in this study, the use of RNAse did not appear to affect the DNA extraction. For all protocols and variables tested,
RNAse did not evolve purer samples. The possibility of eliminating the use of RNAse during DNA extraction also results in the development of a lower cost protocol.

Other variables, however, corroborated with the information available in the literature, such as the use of proteinase $\mathrm{K}$ to increase extraction efficiency, especially at temperatures of sample incubation up to $55^{\circ} \mathrm{C}$. The proteinase $\mathrm{K}$ digestion is characterized by the purification of quality DNA for genetic analyzes such as PCR (Sweeney and Walker, 1993; Goldenberger et al., 1995).

One of the most promising results was the possibility of exploring different incubation times of the samples in the lysis buffer, with a proven spectrum of efficiency in one, 12, 24, and 36 hours, using the ocular tissue of H. commersoni. The advantages related to this discovery are the possibility of extracting the DNA in a single day (one hour at $55^{\circ} \mathrm{C}$ ), incubating the samples overnight, or, furthermore, being able to postpone extraction after tissues incubation in lysis buffer, until 36 hours at room temperature of approximately $27^{\circ} \mathrm{C}$. This result implies that the samples can be transported in situations where the specimens are euthanized in the field and the tissue maintained in lysis buffer without the need for refrigeration or other forms of preservation until the DNA can be extracted at adequate conditions.

In general, all protocols chosen from literature presented relative efficiency in the extraction of $H$. commersoni DNA, despite some limitations, when evaluating the concentration indices obtained from each sample. However, when the values were analyzed under the spectrum of the absorbance ratio equation, it is evident that the protocol proposed in this work was the one that obtained the highest DNA purity values.

Our improved protocol consists of a simple and economical method to obtain DNA from $H$. commersoni, with the potential to be applied in other similar species. Following this methodology that we optimized, it was possible to amplify the samples using PCR-RAPD primers successfully. The samples from the other protocols were also submitted to the same analysis, but without results. Further studies analyzing the samples obtained using our protocol on different genetic studies, and applying other molecular markers should be conducted to expand this discussion.

Under optimal conditions, a single cell contains sufficient DNA to serve as a template for PCR reactions. The efficacy of this protocol in PCR-based genetic studies was confirmed through the amplification of samples using RAPD markers. Our findings brought unprecedented data for the specie Hypostomus commersoni, and this information can be applied in further studies and in the genetic characterization of this important taxon.

\section{Acknowledgments}

The authors thank CAPES, CNPq, FAPERGS, and the Post-Graduation Program in Ecology from URI (Universidade Regional Integrada-Erechim, Brazil), for the financial support and scholarships provided. 


\section{References}

ALI, B.A., HUANG, T.H., QIN DA, N. and WANG, X.M., 2004. A review of random amplified polymorphic DNA (RAPD) markers in fish research. Reviews in Fish Biology and Fisheries, vol. 14, no. 4, pp. 443-453. http://dx.doi.org/10.1007/s11160-005-0815-0.

ALJANABI, S.M. and MARTINEZ, I., 1997. Universal and rapid salt-extraction of high-quality genomic DNA for PCR-based techniques. Nucleic Acids Research, vol. 25, no. 22, pp. 46924693. http://dx.doi.org/10.1093/nar/25.22.4692. PMid:9358185.

ALMEIDA, F.S., FUNGARO, M.H.P. and SODRÉ, L.M.K., 2001. RAPD and isoenzyme analysis of genetic variability in three allied species of catfish (Siluriformes, Pimelodidae) from the Tibagi river, Brazil. Journal of Zoology (London, England), vol. 253, no. 1, pp. 113-120. http://dx.doi.org/10.1017/S0952836901000103.

BALDISSEROTTO, B., 2009. Piscicultura continental no Rio Grande do Sul: situação atual, problemas e perspectivas para o futuro. Ciência Rural, vol. 39, no. 1, pp. 291-299. http://dx.doi. org/10.1590/S0103-84782008005000046.

BARBOSA, C., NOGUEIRA, S., GADANHO, M. and CHAVES, S., 2015. DNA extraction: Finding the most suitable method In: N. COOK, M. D'AGOSTINO and K.C. THOMPSON, eds. Molecular microbial diagnostic methods: Pathways to implementation for the food and water industries. London: Academic Press, pp. 135-154. https://doi.org/10.1016/B978-0-12-416999-9.00007-1

BARBOSA, M.M., 1998. Quantificação e controle da qualidade do DNA genômico. In: S.C.K. MILACH, ed. Marcadores moleculares em plantas. Porto Alegre: SANDRA MILACH, pp. 99-106.

BAREA, J.A., PARDINI, M.I.M.C. and GUSHIKEN, T., 2004. Extração de DNA de materiais de arquivo e fontes escassas para utilização em reação de polimerização em cadeia (PCR). Revista Brasileira de Hematologia e Hemoterapia, vol. 26, no. 4, pp. 274-281. http://dx.doi.org/10.1590/S1516-84842004000400008.

BARRERO, N.M.L., POVH, J.A., RIBEIRO, R.P., GOMES, P.C., JACOMETO, C.B. and LOPES, T.S., 2008. Comparison of DNA extraction protocols of fish fin and larvae samples: modified salt $(\mathrm{NaCl})$ extraction. Ciencia e Investigación Agraria, vol. 35 , pp. 65-74.

BAUER, M. and PATZELT, D., 2003. A method for simultaneous RNA and DNA isolation from dried blood and semen stains. Forensic Science International, vol. 136, no. 1-3, pp. 76-80. http:// dx.doi.org/10.1016/S0379-0738(03)00219-6. PMid:12969623.

BICKEL, T.O., BRÜHL, C.A., GADAU, J.R., HÖLLDOBLER, B. and LINSENMAIR, K.E., 2006. Influence of habitat fragmentation on the genetic variability in leaf litter ant populations in tropical rainforests of Sabah, Borneo. Biodiversity and Conservation, vol. 15, no. 1, pp. 157-175. http://dx.doi.org/10.1007/s10531-004-4248-1.

BUCK, S. and SAZIMA, I., 1995. An assemblage of mailed catfishes (Loricariidae) in southeastern Brazil: distribution, activity, and feeding. Ichthyological Exploration of Freshwaters, vol. 6 , pp. 325-332.

BUENO, V., 2004. DNA e aperfeiçoamento das técnicas de extração. Revista Brasileira de Hematologia e Hemoterapia, vol. 26, no. 4, pp. 233-234. http://dx.doi.org/10.1590/S151684842004000400001 .

BURGESS, W.E. 1989. An atlas of freshwater and marine catfishes - A preliminary survey of the Siluriformes. New Jersey: TFH Publications, Inc.
CHEN, H. and LEIBENGUTH, F., 1995. Studies on multilocus fingerprints, RAPD markers, and mitochondrial DNA of a gynogenetic fish Carrasius auratus fibelio. BIGEBA, vol. 33, no. 9-10, pp. 297-306. http://dx.doi.org/10.1007/BF02399929. PMid:8748455.

CHEN, H., RANGASAMY, M., TAN, S.Y., WANG, H. and SIEGFRIED, B.D., 2010. Evaluation of Five Methods for Total DNA Extraction from Western Corn Rootworm Beetles. PLoS One, vol. 5, no. 8, pp. 11963. http://dx.doi.org/10.1371/journal. pone.0011963. PMid:20730102.

CHIAPPERO, M.B. and GARDENAL, C.N., 2001. Inheritance of random amplified polymorphic DNA (RAPD-PCR) markers and their use in population studies of Calomys musculinus (Rodentia, Muridae), the reservoir of Argentine Hemorrhagic Fever. Hereditas, vol. 135, no. 1, pp. 85-93. http://dx.doi. org/10.1111/j.1601-5223.2001.t01-1-00085.x. PMid:12035619.

COOMBS, N.J., GOUGH, A.C. and PRIMROSE, J.N., 1999. Optimization of DNA and RNA extraction from archival formalinfixed tissue. Nucleic Acids Research, vol. 27, no. 16, pp. 16-12. http://dx.doi.org/10.1093/nar/27.16.e12-i. PMid:10454649.

COOPER, M.L., 2000. Random amplified polymorphic DNA analysis of southern brown bandicoot (Isoodon obesulus) populations in Western Australia reveals genetic differentiation related to environmental variables. Molecular Ecology, vol. 9, no. 4, pp. 469-479. http://dx.doi.org/10.1046/j.1365-294x.2000.00883.x. PMid:10736049.

COPPINI, V.J., 2009. Variabilidade genética em Oligoryzomys nigripes através de marcadores RAPD e cariotipagem, tendo o rio Uruguai como barreira geográfica. Erechim: Programa de Pós-Graduação em Ecologia, Universidade Regional Integrada do Alto Uruguai e das Missões, Dissertação de Mestrado.

DERGAM, J.A., PAIVA, S.R., SCHAEFFER, C.E., GODINHO, A.L. and VEIRA, F., 2002. Phylogeography and RAPD-PCR variation in Hoplias malabaricus (Bloch, 1794) (Pisces, Teleostei) in southeastern Brazil. Genetics and Molecular Biology, vol. 25, no. 4, pp. 379-387. http://dx.doi.org/10.1590/S1415-47572002000400005.

DOYLE, J.J. and DOYLE, J.L., 1987. A rapid DNA isolation procedure for small quantities of fresh leaf tissue. Phytochemical Bulletin, vol. 19, pp. 11-15. http://dx.doi.org/10.12691/jfnr-2-7-6.

FALEIRO, F.G., FALEIRO, A.S.G., CORDEIRO, M.C.R. and KARIA, C.T., 2003. Metodologia para operacionalizar a extração de DNA de espécies nativas do cerrado. Planaltina. Embrapa Cerrados, vol. 1, pp. 1-6.

GARAVELLO, J.C. and GARAVELLO, J.P., 2004. Spatial distribution and interaction of four species of the catfish genus Hypostomus Lacépède with the bottom of Rio São Francisco, Canindé do São Francisco, Sergipe, Brazil (Pisces, Loricariidae, Hypostominae). Brazilian Journal of Biology $=$ Revista Brasileira de Biologia, vol. 64, no. 3B, pp. 103-141. http://dx.doi.org/10.1590/ S1519-69842004000400006. PMid:15619997.

GOLDENBERGER, D., PERSCHIL, I., RITZLER, M. and ALTWEGG, M., 1995. A simple "universal" DNA extraction procedure using SDS and proteinase $\mathrm{K}$ is compatible with direct PCR amplification. PCR Methods and Applications, vol. 4, no. 6, pp. 368-370. http://dx.doi.org/10.1101/gr.4.6.368. PMid:7580932.

GONÇALVES, A.P., 2011. [viewed 28 March 2020] Ecologia e etnoecologia de Hypancistrus zebra (Siluriformes: Loricariidae) no Rio Xingu, Amazônia Brasileira [online]. Belém: Universidade Federal do Pará. Dissertação de Mestrado. Available from: 
http://ppgeap.propesp.ufpa.br/ARQUIVOS/dissertacoes/2011/ PPGEAP_Dissertacao_Alany_Goncalves_2009\%20a\%202011.pdf

LEUZZI, M.S.P., ALMEIDA, F.S., ORSI, M.L. and SODRÉ, L.M.K., 2004. Analysis by RAPD of the genetic structure of Astyanax altiparanae (Pisces, Characiformes) in reservoirs on the Paranapanema river Brazil. Genetics and Molecular Biology, vol. 27, no. 3, pp. 355-362. http://dx.doi.org/10.1590/S141547572004000300009 .

LUCENTINI, L., CAPORALI, S., PALOMBA, A., LANCIONI, H. and PANARA, F., 2006. A comparison of conservative DNA extraction methods from fins and scales of freshwater fish: A useful tool for conservation genetics. Conservation Genetics, vol. 7, no. 6, pp. 1009-2012. http://dx.doi.org/10.1007/s10592-006-9137-6.

LUJAN, N.K., WINEMILLER, K.O. and ARMBRUSTER, J.W., 2012. Trophic diversity in the evolution and community assembly of loricariid catfishes. BMC Evolutionary Biology, vol. 12, no. 1, pp. 124. http://dx.doi.org/10.1186/1471-2148-12-124. PMid:22835218.

MATOSO, D.A., ARTONI, R.F. and GALETTI JUNIOR, P.M., 2004. Genetic diversity of the small characid fish Astyanax sp., and its significance for conservation. Hydrobiologia, vol. 527, no. 1, pp. 223-225. http://dx.doi.org/10.1023/B:HYDR.0000043303.02986.71.

MEDRANO, J.F., AASEN, E. and SHARROW, L., 1990. DNA extraction from nucleated red blood cells. Biotechnology, vol. 8, no. 1, pp. 43. PMid:2182076.

MEGA, N.O. and REVERS, L.F., 2011. Developing a rapid, efficient and low cost method for rapid DNA extraction from arthropods. Ciência Rural, vol. 41, pp. 1563-1570.

MILLIGAN, B.G. 1998. Total DNA isolation. In: HOELZEL, A.R., editor. Molecular genetic analysis of population: $A$ practical approach. 2nd ed. Oxford: Oxford University Press, vol. 2, pp. 29-64.

MOSSI, A.J., COPPINI, V.J., SLAVIERO, L.B., KUBIAK, G.B., LERIN, L.A., OLIVEIRA, J.V., CHEREME, J.J., MARINHO, J.R. and CANSIAN, R.L., 2014. Comparison between Oligoryzomys nigripes and $O$. flavescens by RAPD and genetic diversity in O. nigripes (Rodentia, Cricetidae). Brazilian Journal of Biology $=$ Revista Brasileira de Biologia, vol. v, no. 74, pp. 705-711. http:// dx.doi.org/10.1590/bjb.2014.0084. PMid:25296222.

MUHAMMAD, H., IQBAL, Z., IQBAL, M.U., YOUNAS, T. and BASHIR, Q., 2016. An efficient method for DNA isolation from fish fin. Pakistan Journal of Agricultural Sciences, vol. 53, no. 04, pp. 843-850. http://dx.doi.org/10.21162/PAKJAS/16.3998.

RANTAKOKKO-JALAVA, K. and JALAVA, J., 2002. Optimal DNA isolation method for detection of bacteria in clinical specimens by broad-range PCR. Journal of Clinical Microbiology, vol. 40, no. 11, pp. 4211-4217. http://dx.doi.org/10.1128/JCM.40.11.42114217.2002. PMid:12409400.

REIS, R.E., KULLANDER, S.O. and FERRARI JUNIOR, C.J., 2003. Checklist of the freshwater fishes of South and Central América. Porto Alegre: EDIPUCRS, 742 p.
REISCHL, U., LINDE, H.J., METZ, M., LEPPMEIER, B. and LEHN, N., 2000. Rapid identification of methicillin-resistant Staphylococcus aureus and simultaneous species confirmation using real-time fluorescence PCR. Journal of Clinical Microbiology, vol. 38, no. 6, pp. 2429-2433. http://dx.doi.org/10.1128/JCM.38.6.24292433.2000. PMid:10835024.

SWEENEY, P.J. and WALKER, J.M. 1993. Enzymes of molecular biology. In M.M. BURRELL, ed. Methods in molecular biology. Cambridge: Humana Press, pp.16-305.

TOREZAN, J.M.D., SOUZA, R.F., RUAS, P.M., RUAS, C.F., CAMARGO, E.H. and VANZELA, A.L.L., 2005. Genetic variability of pre and pos-fragmentation cohorts of Aspidosperma polyneuron Muell. Arg. (Apocynaceae). Brazilian Archives of Biology and Technology, vol. 48, no. 2, pp. 171-180. http://dx.doi.org/10.1590/ S1516-89132005000200002.

VAN TONGEREN, S.P., DEGENER, J.E. and HARMSEN, H.J., 2011. Comparison of three rapid and easy bacterial DNA extraction methods for use with quantitative real-time PCR. European Journal of Clinical Microbiology \& Infectious Diseases, vol. 30, no. 9, pp. 1053-1061. http://dx.doi.org/10.1007/s10096-011-1191-4. PMid:21311936.

WANG, T.Y., WANG, L., ZHANG, J.H. and DONG, W.H., 2011. A simplified universal genomic DNA extraction protocol suitable for PCR. Genetics and Molecular Research, vol. 10, no. 1, pp. 519-525. http://dx.doi.org/10.4238/vol10-1 gmr1055. PMid:21476197.

WARD, R.D., HANNER, R. and HEBERT, P.D.N., 2009. The campaign to DNA barcode all fishes, FISH-BOL. Journal of Fish Biology, vol. 74, no. 2, pp. 329-356. http://dx.doi.org/10.1111/j.10958649.2008.02080.x. PMid:20735564.

WASKO, A.P. and GALETTI JUNIOR, P.M., 2002. RAPD analysis in the Neotropical fish Brycon lundii: genetic diversity and its implications for the conservation of the species. Hydrobiologia, vol. 474, no. 1/3, pp. 131-137. http://dx.doi. org/10.1023/A:1016569919615.

WASKO, A.P., MARTINS, C., OLIVEIRA, C. and FORESTI, F., 2003. Non-destructive genetic sampling in fish. An improved method for DNA extraction from fish fins and scales. Hereditas, vol. 138 , no. 3 , pp. 161-165. http://dx.doi.org/10.1034/j.16015223.2003.01503.x. PMid:14641478.

WASKO, A.P., MARTINS, C., OLIVEIRA, C., SENHORINI, J.A. and FORESTI, F., 2004. Genetic monitoring of the Amazonian fish matrinchã (Brycon cephalus) using RAPD markers: insights into supportive breeding and conservation program. Journal of Applied Ichthyology, vol. 20, no. 1, pp. 48-52. http://dx.doi. org/10.1111/j.1439-0426.2004.00479.x.

WHITMORE, D.H., THAI, T.H. and CRAFT, M., 1992. Gene Amplification Permits Minimally Invasive Analysis of Fish Mitochondrial DNA. Transactions of the American Fisheries Society, vol. 12, no. 2, pp. 170-177. http://dx.doi.org/10.1577/15488659(1992)121<0170:GAPMIA>2.3.CO;2. 


\section{Supplementary Material}

Supplementary material accompanies this paper.

S1 - Full description of protocols 1 to 7.

This material is available as part of the online article from http://www.scielo.br/bjb 